Казанішена Наталія

кандидат педагогічних наук, доцент, завідувач кафедри біології та методики її викладання Кам'янець-Подільського національного університету імені Івана Огієнка, м. Кам'янець-Подільський, Україна ORCID: 0000-0002-0837-6905 e-mail:kaz.nat.v@gmail.com

\title{
НАВЧАЛЬНІ ТА ВИРОБНИЧІ ПРАКТИКИ ЯК СКЛАДОВА ПІДГОТОВКИ МАЙБУТНЬОГО ВЧИТЕЛЯ БІОЛОГІЇ ДО ПРОФЕСІЙНОЇ ДІЯЛЬНОСТІ
}

Анотація. У статті здійснено цілісний аналіз педагогічних аспектів організації практичної підготовки майбутнього вчителя біології. На основі освітніх програм визначено компетентності, які мають бути сформовані у студентів під час проведення навчальних та виробничих практик.

3'ясовано значення навчальних польових практик 3 ботаніки та зоології у системі підготовки вчителя. Схарактеризовано їхню мету, завдання, особливості організації. Вказано на зв'язок навчальних польових практик та шкільного курсу біології.

Обгрунтовано значення й завдання навчальної педагогічної практики, яка спрямована на ознайомлення студентів із системою роботи вчителя біології, формами та методами навчання школярів. Зазначено мету, завдання, принципи організації; деталізовано зміст роботи студентів під час активної виробничої педагогічної практики у закладі загальної середньої освіти.

Акцентовано увагу на застосуванні студентами інноваційних методів, засобів, технологій навчання біології. Зокрема, серед обов'язкових завдань для студентів на період практики визначено впровадження проєктного навчання біології, інтерактивних технологій навчання, застосування ігрових технологій навчання, дослідницьких завдань, запровадження комп'ютерних технологій навчання, використання можливостей інтернету в освітньому просторі, проведення нестандартних уроків біології тощо.

Ключові слова: практична підготовка вчителя біології, навчальна та виробнича практика, педагогічна практика.

Постановка проблеми. Сучасна система освіти перебуває на етапі кардинальних змін та оновлення на всіх іï рівнях. Переглядаються структура, завдання, зміст, методичне забезпечення організації освітнього процесу в закладах освіти. Адаптуються до сучасних вимог суспільства, особливостей та потреб сучасного здобувача освіти стандарти освіти, освітні програми, робочі програми дисциплін та інші нормативні 


\section{Інноватика у вихованні. Випуск 13.Том 1. 2021.}

документи.

У зв’язку з активним оновленням завдань, змісту сучасної шкільної біологічної освіти особливої уваги потребує підготовка майбутнього вчителя біології до професійної педагогічної діяльності. Дієвою складовою системи його підготовки у закладі вищої освіти є практика. Саме навчальні та виробничі практики, за умови їхньої цілеспрямованої організації та підпорядкування потребам майбутньої професії здобувачів вищої освіти, забезпечують становлення цілісної особистості вчителя біології.

Аналіз останніх досліджень 3 проблеми. У центрі уваги науковців перебувають різні аспекти проблеми підготовки майбутнього вчителя біології. Питання його професійного становлення та методичної підготовки розглядаються у працях Л. Барни (2006), А. Степанюк (2006), Н. Баюрко (2017), Т. Бондаренко (2011), Н. Грицай (2016), М. Козій (2001), I. Кореневої (2018), С. Люленко (2013), Н. Міщук (2011), В. Мороз (2006), Ю. Шапран (2014) та ін. Зокрема, в зазначених працях приділено увагу реалізації компетентнісного підходу в підготовці вчителя біології, 3'ясовано методичне забезпечення процесу професійного становлення майбутнього вчителя біології, досліджено роль, можливості та шляхи підвищення ефективності теоретичної та практичної підготовки майбутнього фахівця у процесі аудиторних занять та практики тощо.

На нашу думку, особливої уваги та обгрунтування потребує організація практичної підготовки здобувачів вищої освіти. Саме під час навчальних та виробничих практик студенти мають нагоду реалізувати свої знання, вміння й навички, сформовані у процесі аудиторного навчання та самостійної роботи. Однак, попри наявності значної кількості наукових праць 3 проблематики професійної підготовки вчителя біології, вважаємо недостатньо дослідженим питання реалізації можливостей виробничих та навчальних, зокрема польових та педагогічних, практик у становленні майбутнього вчителя біології.

Мета статті - обгрунтувати значення й проаналізувати завдання, зміст, принципи організації навчальних і виробничих практик у процесі фахової підготовки майбутнього вчителя біології у закладі вищої освіти.

Виклад основного матеріалу дослідження. Підготовка вчителя - це цілісна, динамічна, багатокомпонентна та високовпорядкована структура. Вона функціонує відповідно до потреб та запитів суспільства, орієнтуючись на формування системи компетентностей, знань, умінь та навичок здобувачів освіти, розвиток їхніх професійно зорієнтованих потреб, мотивів та цінностей, які, у своїй сукупності, здатні забезпечити виконання професійних обов'язків майбутньому учителю.

Освітньо-професійною програмою підготовки здобувачів вищої освіти за спеціальністю 014 Середня освіта (Біологія та здоров'я людини) у Кам'янець-Подільському національному університеті імені Івана Огієнка визначаються компетентності, які мають бути сформовані у процесі підготовки майбутніх педагогів. Зокрема, передбачено компетентності, які не можуть бути повноцінно сформовані лише під час аудиторного 


\section{Інноватика у вихованні. Випуск 13.Том 1. 2021.}

навчання. Їхня реалізація можлива лише у процесі практичної підготовки здобувачів вищої освіти під час навчальних та виробничих практик. Це такі компетентності, як:

здатність здійснювати безпечні біологічні дослідження в природних умовах, інтерпретувати результати досліджень;

здатність застосовувати набуті знання в практичних ситуаціях;

здатність до адаптації та дії в новій ситуації;

здатність до проектування власної діяльності у сфері навчання біології у закладі загальної середньої освіти;

здатність здійснювати добір методів і засобів навчання біології для розвитку знань та здібностей учнів;

здатність застосовувати сучасні методи й освітні технології для забезпечення високої якості освітнього процесу та ін.

Так, з метою формування компетентності, пов'язаної із здатністю здобувачів вищої освіти здійснювати безпечні біологічні дослідження, освітньо-професійною програмою передбачено низку навчальних дисциплін: «Цитологія, з основами гістології та ембріології», «Ботаніка», «Зоологія», «Фізіологія рослин», «Мікробіологія та вірусологія» та інші. Під час лабораторних занять із зазначених дисциплін студенти мають змогу практично застосувати теоретичні знання, здобуті під час лекційних занять, засвоїти техніку підготовки та проведення практичних i лабораторних робіт, частина яких передбачена програмою шкільного курсу біології.

Проте формування здатності майбутнього вчителя біології здійснювати біологічні дослідження у природних умовах, можливе лише під час навчальних польових практик. Тому в освітньо-професійній програмі. 014 Середня освіта (Біологія та здоров'я людини) визначено навчально-польові практики 3 ботаніки та зоології. Знання, вміння та навички, що формуються у процесі проходження навчальних польових практик необхідні майбутньому вчителеві біології для підготовки практичних і лабораторних робіт до уроків, організації фенологічних спостережень, для урізноманітнення уроків біології, організації польових ботанічних та зоологічних досліджень, для проведення навчальних екскурсій, під час організації гурткової роботи, для підготовки учнівських робіт для конкурсу МАН тощо.

Навчально-польові практики із ботаніки для студентів спеціальності 014 Середня освіта (Біологія та здоров’я людини) заплановані на 2 семестр (морфологія та анатомія рослин) та 4 семестр (систематика рослин). Польові практики з ботаніки проводяться після вивчення відповідних змістових модулів та тем навчальної дисципліни «Ботаніка». Завданнями навчальної польової практики з ботаніки: вивчення у природних умовах біоморфології та систематики характерних представників місцевої флори; формування у студентів практичних навичок щодо збирання колекцій, фіксування та первинна обробка рослинних організмів; з'ясування екологічних особливостей та біологічних взаємозв'язків в основних 


\section{Інноватика у вихованні. Випуск 13.Том 1. 2021.}

рослинних спільнотах; виконання самостійних дослідницьких робіт зі спостереження за рослинними об'єктами; складання ботанічного опису рослини, вміння їі визначати; вивчення життєвих форм рослин, особливостей онтогенезу, вікових та сезонних змін, способів розмноження і розселення рослин; ознайомлення 3 проблемами та заходами 3 охорони рослинного світу.

Організація навчально-польових практик із зоології здійснюється у 2 та 4 семестрах після вивчення начальної дисципліни «Зоологія». Завданнями навчально-польової практики із зоології: оволодіння основними методами збору зоологічного матеріалу; визначення виду тварин за анатомо-морфологічними ознаками та особливостями життєдіяльності; виготовлення та зберігання навчальних та наукових зоологічних колекцій; знайомство 3 видовим різноманіттям тварин у природі, особливостями їх поширення та адаптивними пристосуваннями до проживання у різних умовах середовища; формування уявлень про основні екологічні групи тварин, онтогенез, вікові та сезонні зміни, способи розмноження, їх поширення; спостережень за ростом, розвитком, метаморфозом і розмноженням тварин; знайомство $з$ проблемами охорони тваринного світу.

Навчально-польові практики проводяться на території НПП «Подільські товтри», НПП «Хотинський», РЛП «Мальованка», на базі тимчасових експедиційних таборів. 3 цією метою із базами практик укладено угоди про співпрацю, про спільне проведення науково-дослідної діяльності, експедицій.

3 метою формування інших вище зазначених компетентностей майбутнього вчителя біології освітньо-професійними програмами підготовки здобувачів бакалаврського та магістерського рівнів передбачено педагогічні практики. Це навчальна педагогічна та виробнича педагогічна практики.

Базами для проходження педагогічної практики є заклади загальної середньої освіти, навчально-виховні комплекси, гімназії, ліцеї міста Кам'янця-Подільського та України із високим науково-методичним рівнем забезпечення освітнього процесу, сучасною матеріально-технічною базою та висококваліфікованими педагогами.

Навчальна педагогічна практика запланована для студентів 3 курсу у 6 семестрі. Ї̈і мета - знайомство із системою роботи вчителя біології, 3 особливостями організаційних форм та методів навчання, із матеріальнотехнічною базою закладів освіти.

Навчальна педагогічна практика має ознайомлювальний характер. Вона організовується після вивчення психології та педагогіки. Завданнями практики передбачено: ознайомлення із шкільною документацією (календарним плануванням 3 біології, основ здоров'я, поурочними планами-конспектами, журналом, планом виховної роботи класного керівника тощо), відвідування уроків вчителів біології, основ здоров'я, географії та ін., аналіз відвіданих уроків, виховних заходів у класі, за яким 


\section{Інноватика у вихованні. Випуск 13.Том 1. 2021.}

закріплені практиканти, ознайомлення із матеріально-технічною базою навчання біології тощо. Студенти працюють у 6-9 класах, закріплюються за одним класом, на базі якого виконують усі завдання.

Завдяки безпосередньому сприйманню освітнього процесу з біології у закладі загальної середньої освіти майбутні вчителі усвідомлюють його сутність, а безпосередня участь в освітньому процесі унаочнює засвоєні положення теоретичного навчання, доводить їх правомірність, сприяє осмисленню, систематизації набутих знань.

Наступним етапом у системі практичної підготовки майбутнього вчителя біології $\epsilon$ виробничі педагогічні практики («активні» практики). Плануємо їх після вивчення навчальної дисципліни «Методика навчання біології» у 7-8 семестрах бакалаврату та у 1-2 семестрах магістратури.

Мета виробничої педагогічної практики - формування, поглиблення та систематизація теоретичних знань, практичних умінь і навичок, здібностей, набутих під час попередньої підготовки студентів в освітньому процесі закладу вищої освіти та необхідних для успішного виконання завдань біологічної освіти у майбутній професійній діяльності в умовах закладу загальної середньої освіти.

Мету виробничої педагогічної практики реалізуємо у таких завданнях практики:

закріплювати теоретичні знання та практичні вміння, сформовані у процесі вивчення методики навчання біології;

удосконалювати практичні вміння й навички планувати, організовувати, здійснювати, контролювати, аналізувати, коригувати освітню роботу з біології у закладі загальної середньої освіти, відповідно до вікових, індивідуальних особливостей та особистісних потреб учнів, рівня їхньої підготовки, потреб держави і суспільства;

формувати вміння й навички добирати найбільш ефективні форми, методи, засоби навчання біології, адаптувати їх до шкільних реалій та особливостей класу, учнів, можливостей матеріально-технічної бази школи;

стимулювати інтерес майбутніх учителів біології до професійної педагогічної діяльності;

розвивати уміння об'єктивно оцінювати власну професійну діяльність у закладі освіти, виявляти й усувати недоліки цієї діяльності.

Окреслимо принципи організації виробничої педагогічної практики, якими ми керуємося при ії плануванні й проведенні:

відповідність змісту практики вимогам, поставленим державою та суспільством щодо вчителя та його професійної діяльності;

відповідність змісту та завдань практики освітньо-професійним програмам підготовки фахівців спеціальності 014 Середня освіта (Біологія та здоров'я людини) бакалаврського та магістерського рівнів;

зв'язок завдань практики із лекційними та практичними заняттями;

зв'язок практики 3 життям, що передбачає створення умов, добір системи завдань, які максимально відображають діяльність учителя 3 


\section{Інноватика у вихованні. Випуск 13.Том 1. 2021.}

організації навчання біології;

принцип систематичності та неперервності обумовлює систематичне, регулярне залучення студентів до навчальних та виробничих практик (від польових навчальних до педагогічних виробничих);

поступове та логічне ускладнення змісту й завдань практики, що дає змогу послідовно залучати студентів до виконання системи дій та операцій, необхідних для побудови цілісного та цілеспрямованого процесу біологічної освіти й виховання школярів;

навчально-виховний характер практики: робота студентів має забезпечувати розвиток інтересу майбутніх учителів біології до природничої освіти, виховання учнів та бажання їх здійснювати.

Упродовж виробничої педагогічної практики перед студентами ставимо завдання виконувати наступні види робіт: ознайомитися зі школою, познайомитися іiі керівництвом, вчителями біології, основ здоров'я, класним керівником тощо; систематично вивчати досвід роботи вчителя та класного керівника; ознайомитися із кабінетом біології, зробити опис його стану та навчально-методичного забезпечення; вивчити документацію школи, вчителя, класного керівника, зокрема, проаналізувати календарне планування з біології, план виховної роботи класного керівника та школи на період проходження практики; відвідувати уроки біології, основ здоров'я, географії, екології та інші уроки природничого циклу; із дозволу вчителів відвідувати уроки 3 інших предметів у класах, за якими закріплені; познайомитись з учнями класу, за яким закріплені, проаналізувати успішність учнів 3 біології та інших предметів; розробити та провести пробні уроки біології, основ здоров'я, екології; розробити та провести залікові уроки біології, основ здоров'я, екології; брати участь у виховній та методичній роботі школи, відвідувати виховні заходи класного керівника, вчителя біології; розробити та провести виховні заходи, свята, конкурси на біологічну тематику; готувати наочність, дидактичні матеріали до уроків та виховних заходів; брати участь у гуртковій роботі з біології, природознавства, екології, якщо така ведеться у закладі освіти; аналізувати відвідані та проведені уроки, виховні заходи. Окрім цього, студенти виконують індивідуальне науково-дослідне завдання, завдання із психології та завдання із педагогіки, готують звітну документацію.

Акцентуємо увагу на тому, що студенти бакалаврату у 8 семестрі та магістранти отримують додаткові завдання, пов'язані із застосуванням інноваційних форм, методів, технологій навчання. Зокрема, це стосується обов'язкового застосування інтерактивних методів навчання, організації проектного навчання школярів, запровадження елементів STEM-освіти, активного використання комп'ютерних технологій навчання тощо.

3 метою забезпечення наступності в оволодінні студентами методикою навчання біології у 6-11 класах вважаємо за доцільне у різних семестрах зосередити роботу студентів у різних класах, тобто, пропонуємо у 7 семестрі бакалаврату закріплювати практикантів за 6-7 класами 


\section{Інноватика у вихованні. Випуск 13.Том 1. 2021.}

(викладання біології рослин та біології тварин), у 8 семестрі бакалаврату за 8-9 класами (освоєння методичних особливостей викладання біології людини та загальної біології), а магістрантів 1 курсу - закріплювати за 1011 класами. Це забезпечить поступове ознайомлення не лише 3 особливостями викладання біології у різних класах, але й дасть змогу студентам вивчити з особливості роботи з учнями різного віку.

Цінність виробничих практик полягає у тому, що студенти мають нагоду реалізувати власні знання, вміння, сформовані під час теоретичного навчання. Водночас вони відпрацьовують вміння й навички самостійно готувати та проводити уроки, позаурочні заходи з біології, взаємодіяти зі школярами, аналізувати власну педагогічну діяльність та свою готовність до роботи у школі. Педагогічна практика має мотиваційний характер, оскільки дає змогу практиканту об'єктивно оцінити власну готовність до професійної діяльності та стимулює до подальшого самовдосконалення.

Висновки і перспективи подальших розвідок. Сучасні тенденції розвитку системи освіти в Україні ставлять нові вимоги до якості підготовки вчителя біології. 3 метою їх реалізації у процесі фахового становлення майбутнього вчителя біології у закладі вищої освіти освітніми програмами передбачено навчальні дисципліни загальної та фахової підготовки. Особливу роль у підготовці висококваліфікованого конкурентноспроможного вчителя відіграють практики, які забезпечують практичне застосування здобутих знань, первинне ознайомлення з освітнім процесом закладу освіти, відпрацювання практичних умінь та навичок 3 організації процесу навчання біології, формування стійкого інтересу до професійної діяльності тощо.

Проведене дослідження не вичерпує проблеми організації навчальних та виробничих практик у процесі підготовки майбутнього вчителя біології. Подальшого вивчення потребує питання вдосконалення та урізноманітнення завдань практики, впровадження інноваційних технологій навчання під час практики, адаптація здобувачів освіти та їхня практична підготовка до реалій нової української школи.

\section{СПИСОК ВИКОРИСТАНИХ ДЖЕРЕЛ}

Барна, Л., Барна, М. та Степанюк, А. (2006). Підготовка вчителя біології: компетентнісний підхід. В: Професійні компетениії та компетентності вчителя : матеріали регіонального наук.-практ. семінару. Т.: ТНПУ. СС. 145-146.

Баюрко, Н. (2017) Підготовка майбутніх учителів біології до розвитку екологічної компетентності учнів основної школи : монографія. Вінниця: ТОВ Нілан ЛТД. 256 с.

Бондаренко, Т. (2011). Формування спеціальної методологічної компетенції як найвищого показника професійної готовності вчителя біології. Проблеми підготовки сучасного вчителя, № 3ю СС. 136-141.

Грицай, Н. (2016). Теорія $i$ практика методичної підготовки майбутніх учителів біології: монографія. Рівне: О. Зень. 440 с. 


\section{Інноватика у вихованні. Випуск 13.Том 1. 2021.}

Козій, М. (2001). Психолого-педагогічні умови удосконалення педагогічної практики студентів : метод. посіб. Київ: Нац. пед. ун-т ім. М. П. Драгоманова. 141 с.

Коренева, I. (2018). Компетентності вчителя біології: Погляд крізь освіту для сталого розвитку. Науковий часопис НПУ імені М. П. Драгоманова. Серія 5: Педагогічні науки: реалії та перспективи: зб. наук. праць. Київ: Вид-во НПУ імені М.П. Драгоманова. Вип. 62. СС. 108113.

Люленко, С. (2013). Формування мотивів до природоохоронної роботи у майбутніх вчителів біології. Проблеми підготовки сучасного вчителя. № 8 (2). СC. 177-181.

Міщук, Н. (2011). Професійно-методична компетентність у контексті педагогічної діяльності вчителя біології. Вища освіта України. № 3. T. II (27). Темат. вип. «Вища освіта України у контексті інтеграчії до європейського освітнього простору». СС. 540-545.

Мороз, В. (2006). Сучасні проблеми підготовки вчителя біології. В: Матеріали Всеукраӥнської науково-методичної конференції «Розвиток біологічної освіти в Україні». Мелітополь. СС. 19-23.

Шапран Ю. (2014). Теоретичні $i$ методичні засади формування професійної компетентності майбутніх учителів біології. Доктор педагогічних наук. К. 40 с.

\section{REFERENCES}

Barna, L., Barna, M. ta Stepaniuk, A. (2006). Pidhotovka vchytelia biolohii: kompetentnisnyi pidkhid [Biology teacher training: a competency approach].V: Profesiini kompetentsii ta kompetentnosti vchytelia : materialy rehionalnoho nauk.-prakt. seminaru. Ternopil: TNPU. SS. 145-146. [in Ukrainian].

Baiurko, N. (2017) Pidhotovka maibutnikh uchyteliv biolohii do rozvytku ekolohichnoi kompetentnosti uchniv osnovnoi shkoly : monohrafiia [Future biology teachers' preparation for the development of ecological competence for students of secondary school: a monograph]. Vinnytsia: TOV Nilan LTD. 256 s. [in Ukrainian].

Bondarenko, T. (2011). Formuvannia spetsialnoi metodolohichnoi kompetentsii yak naivyshchoho pokaznyka profesiinoi hotovnosti vchytelia biolohii [Formation of special methodological competence as the highest indicator of professional readiness of a biology teacher] Problemy pidhotovky suchasnoho vchytelia, No 3. SS. 136-141. [in Ukrainian].

Hrytsai, N. (2016). Teoriia i praktyka metodychnoi pidhotovky maibutnikh uchyteliv biolohii: monohrafiia [Theory and practice of methodical training of future teachers of biology: monograph]. Rivne: O.Zen. $440 \mathrm{~s}$. [in Ukrainian].

Kozii, M. (2001). Psykholoho-pedahohichni umovy udoskonalennia pedahohichnoi praktyky studentiv : metod. posib. [Psychological and pedagogical conditions for improving the pedagogical practice of students: a method. Handbook]. K.: Nats. ped. un-t im. M. P. Drahomanova. 141 s. [in Ukrainian]. 
Koreneva, I. (2018). Kompetentnosti vchytelia biolohii: Pohliad kriz osvitu dlia staloho rozvytku [Biology teacher competencies: a view through education for sustainable development]. Naukovyi chasopys NPU imeni M.P. Drahomanova. Seriia 5: Pedahohichni nauky: realii ta perspektyvy: zb. nauk. prats. Kyiv: Vyd-vo NPU imeni M.P. Drahomanova. Vyp. 62. SS. 108-113. [in Ukrainian].

Liulenko, S. (2013). Formuvannia motyviv do pryrodookhoronnoi roboty u maibutnikh vchyteliv biolohii [Formation of motives for environmental work in future biology teachers]. Problemy pidhotovky suchasnoho vchytelia. No 8 (2). SS. 177-181. [in Ukrainian].

Mishchuk, N. (2011). Profesiino-metodychna kompetentnist u konteksti pedahohichnoi diialnosti vchytelia biolohii [Professional and methodological competence in the context of pedagogical activity of a biology teachers]. Vyshcha osvita Ukrainy. No 3. T. II (27). Temat. vyp. "Vyshcha osvita Ukrainy u konteksti intehratsii do yevropeiskoho osvitnoho prostoru". SS. 540-545. [in Ukrainian].

Moroz, V. (2006). Suchasni problemy pidhotovky vchytelia biolohii [Modern problems of biology teacher training]. Materialy Vseukrainskoi naukovo-metodychnoi konferentsii «Rozvytok biolohichnoi osvity v Ukraini». Melitopol. SS. 19-23. [in Ukrainian].

Shapran Yu. (2014). Teoretychni $i$ metodychni zasady formuvannia profesiinoi kompetentnosti maibutnikh uchyteliv biolohii [Theoretical and methodical bases for formation of professional competence for future Biology teachers]. Doctor pedahohichnykh nauk. Kyiv, 40 s. [in Ukrainian].

\title{
EDUCATIONAL AND INDUSTRIAL PRACTICES AS A COMPONENT OF TRAINING A FUTURE BIOLOGY TEACHER FOR PROFESSIONAL ACTIVITY
}

\author{
Natalia Kazanishena \\ Candidate of Pedagogical Sciences, Associate Professor, \\ Head at the Department of Biology and Methods of Teaching Biology \\ Ivan Ohiienko Kamianets-Podilskyi National University, \\ Kamianets-Podilskyi, Ukraine \\ ORCID: 0000-0002-0837-6905 \\ e-mail:kaz.nat.v@gmail.com
}

\begin{abstract}
The article presents a comprehensive analysis of the pedagogical aspects of organizing the practical training of a future biology teacher. On the basis of educational programs, competencies are determined that should be formed in students during educational and production practices. Places for each practice were indicated.

The importance of educational field practices in botany and zoology in the system of teacher training had been analyzed. Their goals, objectives, organization features were characterized. The competencies that can be formed
\end{abstract}




\section{Інноватика у вихованні. Випуск 13.Том 1. 2021.}

in students only during field practice have been determined. The connection between educational field practices and the school course in biology was indicated.

Particular attention was paid to the analysis of the content and features of the organization of pedagogical practices. The significance and tasks of educational pedagogical practice were analyzed. The practice was aimed at acquainting students with the system of work of a biology teacher, with the forms and methods of teaching schoolchildren. The role of industrial pedagogical practices in the system of professional training of a future biology teacher was described in the details. The goals, objectives, principles of organization were determined, the content of the work of students was detailed during active industrial teaching practice in an institution of general secondary education. A qualified teacher must respond in a timely manner to current trends in education. Therefore, we focus on the use by students of innovative methods, means, technologies for teaching biology during teaching practice at school. In particular, among the mandatory tasks for students for the period of practice, we define the introduction of project-based teaching in biology, interactive teaching technologies, the use of game learning technologies, the solution of research problems, the introduction of computer learning technologies, the use of the Internet in the educational space, conducting non-standard biology lessons, and the like.

Keywords: practical training of a biology teacher, educational and industrial practice, pedagogical practice.

Стаття надійшла до редакиії 04.05.2021 p. 